\section{Melawan Kredo Aborsi: "Gerakan Abortion Is Not A Crime Sebagai Sebuah Wacana Tandingan"}

Oleh:

Ade Yulfianto $^{1}$ dan Fullah Jumaynah ${ }^{2}$ dilakukan oleh LSM Samara dalam melawan wacana dominan tentang aborsi di Indonesia.

\section{Kata Kunci:}

Aborsi, AbortionIsNotACrime, LSM Samara, Aktivisme Sosial dan Digital.

\begin{abstract}
ABSTRAK
Aborsi di Indonesia masih menjadi perdebatan panjang dan selama itu pula perempuan kerap kali menjadi pihak yang ada dalam posisi rentan nan riskan. Pasalnya, banyak aborsi yang berlangsung secara tidak aman. WHO memperkirakan 4,2 juta aborsi dilakukan per tahun, 750.000 hingga 1,5 juta dilakukan di Indonesia, 2.500 orang di antaranya berakhir dengan kematian (Wijono, 2000). Aborsi juga kerap dikaitkan dengan persoalan moral, budaya, sosial, hingga agama. Perempuan yang melakukan aborsi dapat serta merta divonis tidak bermoral dan menjadi bagian dari pelaku seks bebas. Padahal kehamilan yang tidak diinginkan tentu disebabkan oleh banyak faktor. Dewasa ini, barulah mulai tumbuh gerakan-gerakan yang membawa pada harapan yang lebih cerah mengenai isu aborsi. Gerakan \#AbortionIsNotaCrime merupakan gerakan sosial dan aktivisme digital global yang menentang kriminalisasi perempuan terhadap aborsi. LSM Samara merupakan salah satu lembaga swadaya yang membawa gerakan ini ke Indonesia. Mereka hadir guna mengurai simpul kusut akan penyelesaian isu aborsi yang sarat akan ketidakadilan sosial. Perempuan sebagai sebuah entitas sosial, tak pernah luput dari dominasi kuasa pengetahuan, baik yang sifatnya patriarkis hingga yang sifatnya politis. Penelitian ini bermaksud melihat dan memahami bagaimana Gerakan \#AbortionIsNotaCrime ini berlangsung dan praktik-praktik aktivisme seperti apa yang
\end{abstract}

\footnotetext{
${ }^{1}$ Ade Yulfianto adalah mahasiswa tingkat akhir di Departemen Sosiologi, Fakultas Ilmu Sosial dan Ilmu Politik, Universitas Gadjah Mada.

2 Fullah Jumaynah adalah mahasiswa tingkat akhir di Departemen Komunikasi Penyiaran Islam, Fakultas Dakwah dan Komunikasi, Universitas Islam Negeri Sunan Kalijaga, Yogyakarta.
}

\section{ABSTRACT}

For most Indonesians, abortion is still perceived a controversial issue. In Indonesia, women are at risk for bearing the consequences of taking abortion especially due to unreliable and or unsafe abortion. According to WHO, there are at least 4,2 million women/year who took unsafe abortion in the world. This numbers include $750,000-1,5$ million/year in Indonesia only and 2,500 women/year had ended up in the death toll (Wijono, 2000). Moreover, abortion is also conceived as a moral problem inflicted by religious and social concerns. Women who took abortion are the subjects for moral judgement for being immoral. By constrast, unwanted pregnancy that gives the cause for taking unsafe abortion can be a result from psychological problem (power relation), social and economic problems. Despite this fact, social movement that gives a hope for safe abortion has been established for a decade. To exemplied this global movement for instance is represented by \#AbortionIsNotaCrime. Therefore \#AbortionIsNotaCrime is a platform for social and digital movements that stands for an act against abortion as a criminal act and gives supports for women who are criminalized for taking abortion. In Indonesia, SAMARA is a local NGO that spans the influence of \#AbortionIsNotaCrime. In response to this act, SAMARA makes its provision on unsafe abortion as a social problem resulted from power relations especially that derives from social injustices. In this context, women are the victims of patriarchal structure and power relations including that derives from the dominant discourse on abortion. Therefore, this article aimed at providing a knowledge on how \#Abortion IsNotaCrime inspires a local NGO like SAMARA for supporting women who took abortion and 
the dissemination of an alternative discourse against the dominant discourse of abortion in Indonesia.

\section{Keywords:}

Aborsi, AbortionIsNotACrime, LSM Samara, Social and Digital Activism

\section{Pendahuluan}

Setiap tahunnya di Indonesia, berjuta-juta perempuan mengalami kehamilan yang tidak direncanakan, dan sebagian besar dari perempuan tersebut memilih untuk mengakhiri kehamilan mereka, walaupun dalam kenyataanya aborsi secara umum adalah illegal. Seperti di negara-negara berkembang lainnya dimana terdapat stigma dan pembatasan yang ketat terhadap aborsi, perempuan Indonesia sering kali mencari bantuan untuk aborsi melalui tenaga-tenaga nonmedis yang menggunakan cara-cara antara lain dengan meminum ramuan-ramuan yang berbahaya dan melakukan pemijatan penguguran kandungan yang membahayakan (Guttmacher Institute, 2008). WHO memperkirakan 4,2 juta aborsi dilakukan per tahun, 750.000 hingga 1,5 juta dilakukan di Indonesia, 2.500 orang di antaranya berakhir dengan kematian (Wijono, 2000). Bahkan menurut data dari Badan Kependudukan dan Keluarga Berencana Nasional (BKKBN) pada tahun 2014, setiap tahunnya selalu terjadi peningkatan hingga sekitar 15\%. WHO pun memperkirakan jumlah aborsi tidak aman semakin meningkat setiap tahunnya di seluruh dunia. Dari tingginya kasus tersebut, sebagian besar yang terjadi adalah tindakan aborsi yang tidak aman.

Banyak yang menganggap bahwa aborsi adalah jalan pintas untuk menutupi kehamilan yang tidak diinginkan. Akibatnya, sejumlah wanita justru mengakses aborsi tidak aman yang dilakukan secara diam-diam di sebuah tempat ilegal. Selama konstruksi mengenai aborsi ini dianggap tabu dan problematis, maka agak sulit orang mendapat pelayanan yang baik karena mereka semua bersembunyi. Sejatinya, dasar hukum mengenai aborsi telah diatur dalam Undang-Undang tentang Kesehatan Tahun 2009 dan Peraturan Pemerintah Nomor 61 Tahun 2014 tentang Kesehatan Reproduksi. Aborsi tidak diizinkan, kecuali dengan alasan kedaruratan medis ibu dan bayi serta bagi korban pemerkosaan. Misalnya, kehamilan terjadi pada wanita yang sudah terlalu tua untuk hamil. Jika kehamilan dibiarkan, dikhawatirkan dapat menyebabkan kematian ibu. Abortus janin pun dapat dilakukan pada usia kandungan kurang dari 8 minggu (Kompas, 2016).

Meskipun sudah memiliki dasar hukum, status aborsi di Indonesia masih mengedepankan alasan darurat dan khusus. Artinya, perempuan yang akan melakukan aborsi tidak diperbolehkan ketika tidak memiliki sebab-musabab yang sudah dijelaskan tadi. Ditambah isu aborsi sendiri merupakan isu yang sangat merugikan perempuan dari segala aspek tatkala ia tak memiliki otoritas untuk menentukan tubuhnya sendiri. Alhasil, banyak yang kemudian memilih untuk melakukan aborsi secara sembunyi-sembunyi dan cenderung tidak aman. Situasi terkait aborsi tidak aman di Indonesia kurang lebih banyak dipengaruhi oleh situasi hukum dan sosial yang ada. Di Indonesia, ketika menginginkan pelayanan aborsi yang aman, nyaris tidak ada dokter dan Rumah Sakit "pemerintah atau swasta" yang mau membantu. Begitu juga saat perempuan berkata bahwa ia tidak menghendaki kehamilannya, dokter akan menolak. Kebanyakan para dokter menganggap bahwa kehidupan telah dimulai saat sel telur dan sperma bertemu dan mereka mempunyai hak untuk hidup. Karena itu aborsi dipandang sebagai kejahatan terhadap nyawa. Juga hukum yang membatasi pelegalan aborsi menjadi penghambat akses aborsi aman untuk perempuan di Indonesia.

Oleh sebab itu, tidak banyak data terkini terkait dengan aborsi di Indonesia, karena praktiknya banyak dilakukan secara sembunyi-sembunyi dan berakhir dengan proses kriminalisasi, dan membuat penggalian data terbaru terkendala. Hal 
tersebut kemudian membawa aborsi tidak aman dipilih sebagai jalan keluar yang bisa dilalui. Aborsi tidak aman biasanya dilakukan dengan menemui dukun pijat dan melakukan aborsi sendiri dengan cara tradisional atau penggunaan obat tertentu yang tidak sesuai dengan panduan aborsi aman dari aturan dunia medis.

Wacana dominan mengenai aborsi yang berkembang terhadap perempuan betulbetul menempatkannya dalam simpul yang problematis. Perempuan yang melakukan aborsi akan dianggap sebagai perempuan tidak baik dan telah membunuh janin untuk menghilangkan hak hidup calon bayi yang dikandungnya. Di sini dogma agama juga sangat mempengaruhi bagaimana pandangan masyarakat terhadap aborsi. Agama melarang aborsi karena dianggap sebagai perbuatan dosa atau melanggar aturan agama. Namun, agama juga tidak memberikan solusi atas banyaknya kasus kekerasan seksual berupa kehamilan yang tidak diinginkan, dan berujung pada aborsi.

Beruntung, dewasa ini isu aborsi mulai masuk dalam babak baru yang memberi secercah harapan. Banyak aktivis, intelektual hingga tenaga profesional (medis) mulai melihat kejanggalan dari wacana dominan mengenai aborsi ini. Belakangan, muncul gerakan bernama \#AbortionIsNotACrime. Sebuah gerakan yang muncul sebagai respon terhadap kriminalisasi terhadap perempuan yang melakukan aborsi. Di Indonesia sendiri gerakan ini mulai menyeruak dan diprakarsai oleh sebuah LSM bernama Samsara Indonesia. Samsara merupakan LSM non profit yang bekerja untuk mempromosikan kesehatan reperoduksi, seksualitas, gender, agama, budaya dan spiritualitas dalam isu aborsi. Selain itu, Samsara juga menyediakan program pemulihan mental paska aborsi dan memberi edukasi melalui Sekolah Seksualitas dan Kesehatan Reproduksi.

Melalui gerakannya, Samsara mencoba hadir memberikan pendekatan baru atas isu aborsi. Sebagai LSM yang bergerak dalam isu aborsi, Samsara melalui websitenya "Samsara.or.id" menghadirkan beragam pendidikan terkait Sexsuality and Reproductive Health (SRHR) serta menyediakan layanan advokasi untuk aborsi dengan menyediakan hotline layanan. Diharapkan para perempuan yang tengah kebingungan dalam memutuskan persoalan aborsi ini dapat bercerita atau curhat dan mencarikan solusi terbaik. Kiprah Samsara mampu menjangkau perempuan di berbagai daerah di Indonesia. Layanan hotline yang disediakan oleh Samsara tidak hanya untuk lokal Yogyakarta, melainkan Indonesia bahkan internasional. Selain itu, layanan yang diberikan oleh Samsara juga tanpa memandang status pernikahannya. Sehingga, layanan ini cukup ramah terhadap remaja yang mengalami kehamilan tidak direncanakan. Tentu, gerakan yang dibangun oleh Samsara ini diharapkan mampu menjadi alternatif perubahan dalam isu aborsi. Khususnya dalam pemenuhan hak-hak kesehatan perempuan.

Berdasarkan latar belakang yang sudah dipaparkan tersebut, tulisan ini bermaksud mengidentifikasi; 1) Bagaimana gerakan "AbortionIsNotaCrime" melawan wacana dominan mengenai isu aborsi? Pertanyaan ini bermaksud melacak bagaimana sebabmusabab kemunculan gerakan ini beserta strategi dan wacana apa yang coba diperjuangkan. 2) Bagaimana aktivisme digital yang dilakukan oleh LSM Samara dalam membawa gerakan "AbortionIsNotaCrime" menjadi sebuah kesadaran baru di masyarakat? Pertanyaan ini bermaksud untuk melihat bagaimana kemunculan LSM Samara dan kiprahnya pada isu aborsi di Indonesia, dan sekaligus ingin melihat aktivisme digital seperti apa yang dilakukan oleh LSM Samara sebagai medium gerakannya.

\section{Metodologi}

Penelitian ini menggunakan metode analisis konten atau analisis isi. Secara umum, analisis isi berupaya mengungkap berbagai informasi di balik data yang disajikan di media atau teks. Analisis isi dapat didefinisikan sebagai teknik mengumpulkan dan menganalisis isi dari suatu teks. "isi" dalam hal ini dapat berupa kata, arti 
(makna), gambar, simbol, ide, tema, atau beberapa pesan yang dapat dikomunikasikan (Neuman, 2003). Adapun teks-teks yang akan dianalisis nantinya adalah informasi-informasi mengenai isu aborsi yang terdapat di portal-portal website dan data-data yang terdapat di laman LSM Samara.

\section{KAJIAN TEORI}

\section{Normalisasi Seksualitas menurut Michael Foucault}

Kuasa tidak bekerja melalui penindasan dan represi, tetapi terutama melalui normalisasi dan regulasi. Menurut Foucault, kuasa tidak bersifat subjektif. Kuasa tidak bekerja dengan cara negatif dan represif, melainkan dengan cara positif dan produktif. Kuasa memproduksi realitas, memproduksi lingkup-lingkup objek, dan ritus-ritus kebenaran. Strategi kuasa tidak bekerja melalui penindasan (secara langsung), melainkan melalui normalisasi dan regulasi, menghukum dan membentuk publik yang disiplin. Publik tidak dikontrol lewat kekuasaan yang bersifat fisik, tetapi dikontrol, diatur, dan didisiplinkan lewat wacana. Kekuasaan dalam pandangan Foucault disalurkan melalui hubungan sosial, dimana memproduksi bentuk-bentuk kategorisasi perilaku sebagai baik atau buruk, sebagai bentuk pengendalian perilaku. Relasi sosial itulah yang memproduksi bentuk subjektifitas dan perilaku lebih dari secara sederhana digambarkan sebagai bentuk restriksi (pembatasan). Akhirnya, khalayak ditundukkan bukan dengan cara kontrol yang bersifat langsung dan fisik, tetapi dengan wacana dan mekanisme berupa prosedur, aturan, tatacara, dan sebagainya. (Eriyanto, 2001) Masalah ini terutama diuraikan oleh Foucault dalam bukunya "Discipline and Punish: The Birth of Prison".

Foucault beranggapan bahwa setiap hubungan sosial selalu merupakan hubungan kekuasaan (hegemoni kekuasaan). Kekuasaan ada dalam setiap hubungan sosial. Dengan kata lain, Power being the ultimate principle of social reality (Basrowi, 2004: 73). Kekuasaan yang menjadi dasar realitas sosial dalam pandangan Foucault bersifat produktif dan tidak kelihatan karena ia ada di mana-mana, menyebar dan menyusup dalam setiap aspek kehidupan, serta terserap dalam ilmu pengetahuan dan praktik sosial yang untuk selanjutnya menciptakan rezim kebenaran. Dengan sifat yang demikian itu, keberlangsungan kekuasaan itu seolah-olah menjadi tidak disadari lagi oleh seseorang. Seseorang rela melaksanakan apa yang dikehendaki oleh kekuasaan tanpa orang itu sendiri menyadari bahkan orang itu sedang dikuasai.

Jenis kekuasaan seperti ini disebut sebagai kekuasaan kedisiplinan atau disciplinary power. Ia membawa efek kepatuhan berada dalam wacana disiplin. Dengan kata lain, suatu cara menegakkan kekuasaan yang bekerja melalui normalisasi. Ia merupakan suatu teknologi untuk menormalisasi kehidupan masyarakat. Jadi, ide tentang kenormalan tidak lain merupakan konstruksi sosial yang dibangun melalui wacana dominan. Wacana ini kemudian melahirkan praktik-praktik seperti mendifinisikan, mengkategorikan, dan mengukur kenormalan itu sendiri. Semua itu kemudian menjadi rutin dan diterima begitu saja sebagai sebagai suatu keharusan yang hendak dilakukan. (Eriyanto, 2001)

Salah satu bidang normalisasi adalah tubuh. Keadaan tubuh seperti (langsing, gemuk, kurus dll), cara berpakaian, dan kesehatan. Dalam semuanya itu berlangsung normalisasi dan dengan itu juga strategi kuasa. Contoh lain yang lebih jelas tentang strategi kuasa adalah seluruh wilayah yang menyangkut kesehatan badani dan psikis dengan norma-normanya untuk menyatakan seseorang sakit atau sehat. Aborsi merupakan salah satu wujud dari normalisasi kekuasaan. Bahwa perempuan yang melakukan aborsi sejatinya merupakan simbol bahwa ia tak lagi suci. Ia harus dinormalkan dengan cara pengucilan, bullying, bahkan kriminalisasi. Salah satu subjek penting yang diamati Foucault menyangkut kekuasaan adalah tubuh, karena baginya untuk menunjukkan bagaimana kuasa melakukan normalisasi dan menyebar, maka haruslah melihat dari 
tubuh manusia. Bahkan bagi Foucault tubuh telah menjadi "pertarungan wacana" terus menerus (Ritzer, George, Smart; 2011)

\section{PEMBAHASAN}

\section{Gerakan "AbortionIsNotACrime" untuk Masa Depan}

\begin{abstract}
Gerakan merupakan gerakan global untuk menentang kriminalisasi terhadap perempuan yang melakukan aborsi. Sejauh ini fenomena aborsi selalu berakhir dengan menjadikan pihak perempuan sebagai pelaku yang dapat disalahkan. Mulai dari alasan kehamilandi luar pernikahan, seksbebas, hingga pembunuhan janin. Ketika aborsi dimaknai sebagai perbuatan kriminal atau kejahatan, perempuan akan menjadi pihak yang paling menderita. Namun, dewasa ini dukungan mulai datang silih berganti untuk menyuarakan kesehatan dan hak-hak perempuan di seluruh dunia agar dapat mengakses dan melaksanakan aborsi secara aman.
\end{abstract}

Dalam beberapa tahun terakhir, badanbadan internasional seperti PBB dan berbagai pemimpin dunia telah mulai meminta pemerintah untuk memenuhi hak seksual dan reproduksi perempuan untuk melaksanakan aborsi yang aman. Gerakan global pun lantas muncul melalui media sosial dan teknologi digital lainnya, yang memungkinkan pendukung dari segala belahan dunia untuk mengidentifikasi tujuan bersama, menggabungkan suara mereka, dan menginspirasi satu sama lain dengan pendekatan baru untuk aktivisme.

Gerakan "AbortionIsNotACrime" lantas muncul sebagai sebuah spirit dan gagasan yang harus diusung untuk mengakhiri penindasan terhadap perempuan. Gerakan ini terus menyuarakan bahwa perempuan dalam isu aborsi haruslah dilindungi dan tidak diletakkan sebagai simpul masalah. Selain itu isu aborsi sering dikesampingkan penyelesaiannya dan dianggap sebagai masalah tunggal si pelaku. Padahal, isu aborsi ini merupakan tanggung jawab bersama kita sebagai masyarakat yang menjunjung tinggi nilai-nilai humanisme.

\section{Melawan Kredo Aborsi: Asal Muasal Gerakan "AbortionIsNotACrime"}

Wacana mengenai gerakan aborsi yang aman dan legal terus diupayakan oleh banyak negara agar dapat menjadi tren global. Pada tahun 2016, Komisi Afrika tentang Hak Asasi Manusia dan Rakyat (ACHPR) mengumumkan kampanye (pada level benua) untuk melegalkan aborsi di Afrika. ACHPR menyerukan Kepala Negara dan Pemerintahan untuk menunjukkan komitmen mereka guna melindungi kehidupan perempuan dan anak perempuan di Afrika dengan melakukan dekriminalisasi aborsi di negara masingmasing.

Di bawah payung Kampanye Internasional untuk Hak Perempuan untuk Aborsi Aman, aktivis di seluruh dunia berkumpul untuk melakukan kampanye dan advokasi, serta nantinya kampanye ini diupayakan dapat tersebar baik di tingkat lokal sampai di tingkat regional. Para aktivis perempuan tersebut berkumpul untuk berbagi pengalaman dan harapan mereka untuk masa depan. Mereka mengakui bahwa perempuan di mana-mana menghadapi hambatan yang sama untuk mengakses aborsi yang aman. Dan seperti yang mereka lakukan, visi bersama untuk masa depan adalah membentuk sebuah dunia di mana semua perempuan dan anak perempuan dapat memenuhi hak mereka untuk melakukan aborsi secara aman dan legal. Yang terpenting, inti dari gerakan ini adalah membawa perempuan untuk dapat membuat pilihan mereka sendiri tentang kesehatan reproduksi secara otonom.

Fenomena aborsi sejatinya merupakan fenomena yang sangat pelik. Ia ada dalam persimpangan antara ketidakadilan akibat hegemoni patriarki dengan norma sosialagama-kebudayaan yang berlangsung. Sebagai contoh di Rwanda, sebuah negara di Afrika Tengah. Ratusan perempuan dan anak perempuan di Rwanda secara tidak adil dilecehkan, ditangkap, diadili dan dipenjarakan setiap tahun atas tuduhan 
terkait aborsi. Sebuah laporan ditahun 2015 berjudul, When Abortion Is a Crime: Rwanda, meskipun hukum pidana Rwanda direvisi pada tahun 2012 dengan mengizinkan aborsi untuk beberapa indikasi, laporan tersebut menggambarkan bagaimana hukum, budaya, dan hambatan lain membuatnya "hampir mustahil" bagi perempuan untuk mendapatkan perlindungan, dengan cara aborsi yang aman dan legal. Undang-undang mengharuskan perempuan yang ingin melakukan aborsi karena alasan kesehatan, setidaknya mendapatkan persetujuan dari dua dokter, sebuah hambatan yang besar untuk dilaksanakan oleh negara dengan kondisi perbandingan satu dokter untuk setiap 17.000 orang. Selain itu, perempuan yang akan melakukan aborsi karena kasus pemerkosaan, inses atau kawin paksa harus terlebih dahulu mendapatkan persetujuan dari hakim. Hal ini menjadi hambatan besar yang lain karena sebagian besar perempuan di Rwanda tinggal di daerah pedesaan dengan akses terbatas ke pengadilan.

Selain Rwanda, kasus lain juga terjadi di Amerika Latin. Beberapa aturan mengenai aborsi yang paling ketat di dunia berada di Amerika Latin, tempat kelahiran Global Day of Action for Access to Safe and Legal Abortion yang diperingati setiap tanggal 28 September. Nikaragua, El Salvador, Chili, Honduras dan Republik Dominika, merupakan negara yang melarang aborsi sepenuhnya, bahkan ketika kehidupan seorang perempuan berada dalam bahaya. Nikaragua melarang aborsi sejak 10 tahun yang lalu. Hal ini lantas memunculkan gelombang protes dari para aktivis perempuan di sana. Para aktivis feminis di wilayah ini telah lama melakukan advokasi tentang hak-hak aborsi sebagai tujuan utama dari gerakannya. Gerakan tersebut misalnya mereka langsungkan dalam acara Festival Puisi Internasional 2012 di Granada, Nikaragua. Mereka kemudian menutupi kota dengan poster-poster yang menampilkan statistik kekerasan seksual dan menyerukan pemerintah untuk menekan tingginya tingkat kekerasan terhadap perempuan dan yang utama adalah dengan melegalkan aborsi. Mereka juga menggelar demonstrasi dramatis di mana perempuan berbaring di jalan memegang bunga berkabung sebagai simbol bagi mereka yang telah meninggal karena larangan total aborsi Nikaragua. Fenomena ini lantas menjadi contoh bahwa persoalan aborsi sejatinya menjadi tanggung jawab pemerintah sebagai pihak yang paling memiliki otoritas dalam mempromosikan dan menegakkan hak-hak seksual dan reproduksi perempuan.

Beberapa negara lantas membuat aturan yang mendukung dilakukannya aborsi secara aman, legal, dan mudah diakses. Negara-negara tersebut diantaranya adalah; Sierra Laone (Afrika Barat), Meksiko, serta Nepal. Pada 2015, parlemen di Sierra Leone memilih mendukung undang-undang aborsi baru yang akan membuat aborsi menjadi aman dan legal. Peraturan ini mendapatkan dukungan yang luar biasa dengan tidak ada pihak yang menolak RUU tersebut. Menurut WHO, Sierra Leone memiliki rasio tertinggi kematian ibu di dunia, termasuk kontribusi yang signifikan (30 persen) dari aborsi yang tidak aman. Diperkirakan 400 perempuan muncul dalam mendukung RUU aborsi aman dengan menggunakan jargon "anak ada karena pilihan, bukan karena paksaan". Pembatasan hukum tentang aborsi hanya membuat aborsi menjadi tidak aman, yang justru akan mengarah pada tingginya kematian ibu (hamil). RUU ini memiliki kekuatan untuk mengubah keadaan menjadi lebih baik.

Sedangkan di Meksiko, sejak legalisasi pada tahun 2007, ratusan ribu perempuan telah menerima aborsi secara legal. Para aktivis bekerja keras menemukan solusi inovatif untuk membantu perempuan mengatasi hambatan melalui pembentukan sistem kesehatan masyarakat. Terakhir di Nepal, sebelum legalisasi aborsi terjadi pada tahun 2002, hingga seperlima dari perempuan di penjara negara itu dihukum atas tuduhan aborsi ilegal dan tidak aman. Di sisi lain aborsi yang tidak aman adalah penyebab utama kematian ibu di Nepal. Tapi karena perubahan aturan, Kementerian Kesehatan Nepal -bekerjasama dengan Ipas dan mitra lainnya-telah mendirikan layanan publik dan swasta di seluruh negeri dan melatih ribuan penyedia jasa terkait untuk melakukan aborsi yang aman. Pemerintah 
Nepal mengalokasikan anggaran untuk menjamin hak-hak reproduksi perempuan dengan memperoleh pelayanan kesehatan yang mendasar dengan menawarkan perawatan berbasis rumah sakit. Program pemerintah Nepal tersebut pada akhirnya menjadi model untuk sebagian besar negara-negara di dunia yang menerapkan aborsi secara aman dan legal. Lebih jauh dari itu, pemerintah Nepal akhirnya menjadikan program layanan ini menjadi gratis sehingga dapat diakses oleh siapapun. Hal ini tentu menunjukkan sebuah harapan besar bahwa gerakan "AbortionIsNotACrime" telah membawa dampak yang signifikan.

Hanya sedikit orang yang menyadari bahwa perempuan benar-benar pergi ke penjara di negara-negara di mana aborsi adalah ilegal. Ketika persoalan aborsi dianggap sebagai sesuatu yang ilegal, perempuan tidak hanya mengambil jalan untuk melakukan aborsi secara tidak aman dan mendapati resiko kematian atau cedera sebagai akibatnya, tetapi mereka dapat dituntut atas tindakan tersebut dan dapat dikirim ke penjara. Publik perlu ditingkatkan kesadarannya mengenai konsekuensi tragis dari hukum mengenai aborsi. Alasan tersebut lantas menjadi tujuan utama dari gerakan aborsi aman untuk nantinya dapat diwujudkan menjadi aturan yang legal.

\section{Aborsi sebagai Produk Kekuasaan dan Normalisasi Tubuh}

Secara sosiologis, begitu problematisnya isu aborsi ini merupakan bentuk dari dominasi patriarki yang masih membelenggu dunia keadilan gender. Dalam kasus ini dominasi patriarki berperan penting di dalamnya. Sylvia Walby, dalam bukunya Theorizing Patriarchy (1990) telah membedakan enam lokasi dari hubungan patriarkal: seksualitas, rumah tangga, kekerasan laki-laki terhadap perempuan, upah kerja, lembaga budaya, dan negara. Aborsi merupakan salah satu wujud dimana perempuan tidak mempunyai kontrol atas tubuh sendiri. Kontrol di sini adalah atas potensi produktif dan reproduksi perempuan. Kontrol tidak hanya materi, tetapi juga ideologi yang kemudian menciptakan penerimaan hegemonik patriarki terhadap perempuan.

Hegemoni patriarki dalam kasus aborsi ini berkembang dalam lingkup masyarakat. Membicarakan kesehatan reproduksi, kontrasepsi, dan segala persoalan seksualitas masih dianggap tabu. Bahkan berkembang stigma-stigma negatif, seperti pada pemakaian kontrasepsi. Stigma terhadap pemakaian kontrasepsi yang berkembang adalah kontrasepsi memiliki berbagai efek samping yang ditimbulkan, merasa stigmatisasi atau berpikir masih ada resiko bagi kehamilan. Sehingga pada akhirnya, tidak diperlukan penggunaan kontrasepsi yang semestinya bisa untuk meminimalisir kehamilan tidak diinginkan. Dominasi yang paling kentara adalah apabila menggunakan kontrasepsi, maka hubungan seksual akan menjadi tidak "nyaman", perempuan tidak dapat "memuaskan" laki-laki (pasangannya). Di sinilah kontrol atas tubuh perempuan diperankan oleh dominasi patriarki.

Pada akhirnya, ketika perempuan menjadi tidak berdaya atas stigma-stigma yang berkembang ketika terjadi kehamilan yang tidak diinginkan pun lagi-lagi perempuan menjadi objek yang disalahkan. Stigma yang berkembang bahwa perempuan yang melakukan aborsi adalah perempuan nakal dan telah membunuh janin dan menghilangkan hak hidup. Di sini dogma agama juga sangat mempengaruhi bagaimana pandangan masyarakat terhadap aborsi. Agama melarang aborsi karena dianggap sebagai perbuatan dosa atau melanggar aturan agama. Namun, agama juga tidak memberikan solusi atas banyaknya kasus kekerasan seksual berupa kehamilan yang tidak diinginkan, dan berujung pada aborsi.

Situasi yang rumit ini tak luput juga dari persoalan struktur kekuasaan yang membelenggu makna aborsi itu sendiri. Mengadopsi teori kuasa dari Foucault (Discipline and Punish: The Birth of Prison, 1995) yang menjelaskan bahwasannya kuasa itu bekerja lewat regulasi dan normalisasi, lewat normalisasi dan regulasilah masyarakat digerakkan. Dalam 
kasus ini, maka aturan yang menabukan perempuan untuk berbicara dan membahas mengenai seks, kesehatan reproduksi, hingga aborsi adalah salah satu bentuk kuasa yang bekerja dalam masyarakat. Efeknya dapat dilihat dari ekslusi terhadap perempuan yang berbicara atau "mendekati" seks secara gamblang, biasanya mereka akan dicap sebagai bukan wanita "baik-baik". Terlebih dalam kasus aborsi ini, perempuan yang melakukan aborsi akan dicap sebagai seorang kriminal dan pendosa sebagai konsekuensi dari belenggu norma sosial dan agama yang berkembang.

Sebagai gerakan yang lahir dari isu atau realita yang berkembang di ruang sosial dan untuk mencapai apa yang menjadi tujuan tidak bisa dilepaskan dari relasi kekuasaan. Foucault menjelaskan wacana selalu bersumber dari pihak yang memiliki kekuasaan dan dari mereka yang memiliki kreatif. Maka, bagaimana wacana tentang aborsi yang saat ini berkembang tak lepas dari siapa yang sedang berkuasa saat ini. Di Indonesia kekuasaan saat ini dibawah hegemoni patriarki dimana dogma agama turut andil berkuasa atas tubuh perempuan. Permasalahan aborsi tidak bisa dilepaskan dari persoalan seksualitas dan tubuh perempuan. Ada represi yang dilakukan oleh penguasa terhadap wacana seks dan tubuh perempuan melalui beragam aturanya dari mulai UU, KUHP, dan PP.

Dalam kondisi tersebut counter wacana sangatlah diperlukan. Satu hal yang dapat dijadikan sebagai pijakan untuk mencari solusi dalam upaya mengembalikan wacana aborsi kembali ke martabat kemanusiaannya haruslah menjadi usaha kolektif yang berangkat dari kesadaran semua pihak sehingga tidak lagi terjadi paradoks dan ambiguitas dalam memandang problematika kehidupan seksual dalam masyarakat. Gerakan "AbortionIsNotACrime" menjadi pemrakarsa yang diharapkan mampu melawan wacana dominan mengenai aborsi dan membawa pada perubahan cara pandang yang lebih humanis.

\section{LSM Samsara, Strategi Gerakan Digital, dan Harapan Aborsi Aman di Indonesia}

Samsara merupakan LSM non profit yang bekerja untuk mempromosikan kesehatan reperoduksi, seksualitas, gender, agama, budaya dan spiritualitas dalam isu aborsi. Selain itu, Samsara juga menyediakan program pemulihan mental paska aborsi dan memberi edukasi melalui Sekolah Seksualitas dan Kesehatan Reproduksi. Bermula dari gerakan digital, Inna Hudaya memulai Samsara sebagai sebuah blog untuk informasi dan edukasi mengenai SRHR pada tahun 2007. Menyusul banyaknya masukan dari kalangan aktivis perempuan, Inna bersama rekannya memperluas blog sebagai sumber dan dukungan bagi perempuan dengan kehamilan yang tidak direncanakan. Dimana perempuan dapat berbagi cerita dan mengajukan pertanyaan yang berkaitan dengan kehamilan dan aborsi mereka. Sampai satu tahun kemudian, pada tanggal 20 April 2008 Inna Hudaya bersama dua rekannya Kikie Nikujuluw dan Grace Clarissa Susetyo di Jakarta memulai inisiatif untuk membangun Samsara sebagai sebuah LSM.

Kini, Samsara hadir sebagai layanan konseling untuk kehamilan tidak direncanakan dan kontrasepsi. Salah satu metode yang digunakan Samsara adalah dengan menyediakan hotline untuk membicarakan atau konseling perencanaan masa depan terkait kehamilan tidak direncanakan dan aborsi. Samsara memandang bahwa akses pendidikan dan informasi SRHR dan aborsi yang aman adalah sebuah hak. Misi Samsara yang utama adalah mempromosikan 'Otonomi Tubuh Perempuan' untuk meningkatkan akses ke pendidikan, informasi dan konseling tentang hak seksualitas dan kesehatan reproduksi. Selain itu juga advokasi untuk informasi dan akses ke perawatan aborsi yang aman. Samsara berpandangan bahwa perempuan memiliki hak dan kewenangan untuk membuat keputusan atas tubuhnya sendiri.

Setiap tahunnya, Samsara kerap mengadakan aktivitas-aktivitas dari mulai 
edukasi sampai dengan kampanye. Dari mulai aktivitas yang berbasis online maupun yang berbasis offline (langsung). Untuk aktivitas yang berbasis offline, Samsara memiliki program bernama it's my circle. Yakni sebuh kampanye positif untuk mengklaim hak reproduksi perempuan yang dilakukan oleh Samsara sejak tahun 2011 hingga 2014. Perempuan sebagai pemilik tubuh, terutama pemilik rahim adalah penentu otoritas atas tubuhnya. Pada faktanya, tubuh dan seksualitas perempuan saat ini dikontrol oleh negara, agama dan budaya. Selain sebagai kampanye atas otoritas tubuh, juga kampanye pada kehamilan tidak direncanakan dan dibutuhkan akses aborsi aman dan legal sebagai salah satu pilihan perempuan. Dalam aktvitasnya, it's $M y$ Circle berusaha untuk memobilisasi massa untuk sama-sama melakukan kampanye dengan mengadakan flashmoob sebagai simbol perjuangan. Kegiatan ini biasanya dilaksanakan menjelang hari Safe Abortion International yang jatuh pada tanggal 28 September.

Selain itu ada pula kegiatan bernama training misoprostol. Dalam kegiatan tersebut, Samsara melakukan aktivitas edukasi secara langsung dengan bertemu masyarakat. Pelatihan ini dimaksudkan untuk meningkatkan pengetahuan dan akses perempuan terhadap teknologi kesehatan untuk meningkatkan status kesehatan maternal perempuan di Indonesia. Selain itu, para peserta juga dibekali ketrampilan konseling kehamilan tidak direncanakan (KTD) untuk dapat menjadi konselor sebaya bagi komunitasnya masing-masing.

Sedangkan untuk aktivisme yang berbasis online, Samsara membuka layanan hotline untuk memfasilitasi perempuan yang ingin curhat. Hotline Samsara ini merupakan program layanan konseling untuk perempuan dengan kehamilan tidak direncanakan. Program ini pertama kali dimulai pada tahun 2008 dengan menyasar perempuan yang mengalami stress paska aborsi melalui media e-mail, telpon, atau tatap muka. Namun sejak 2010, berdasarkan evaluasi terhadap program yang telah dijalankan, layanan konseling Samsara dikembangkan menjadi konseling kehamilan tidak direncanakan dan aborsi sampai sekarang. Dalam konseling ini perempuan dan pasangannya akan berbicara dengan konselor mengenai pilihan-pilihan yang dimungkinkan untuk perempuan saat kehamilan tidak direncanakan terjadi. Melalui media hotline dan email layanan konseling KTD, Samsara telah menjangkau perempuan di berbagai daerah di Indonesia baik yang berada di kota maupun pedesaan, dan tanpa memandang status pernikahannya. Oleh sebab itu, layanan ini cukup ramah terhadap remaja yang mengalami kehamilan tidak direncanakan.

Samsara dalam memprakarsai gerakan "AbortionIsNotaCrime" banyak menggunakan aktivisme digital. Samsara memanfaatkan semua akses digitalnya untuk mengampanyekan gerakan "AbortionIsNotaCrime." Seperti melalui poster-poster yang kerap diunggah melalui Instagram, melalui artikel yang ada di web www.askinna.com, serta tak luput Samsara menyematkan hashtag (\#) dengan tulisan \#AbortionIsNotACrime. Hashtag inilah yang saat ini menjadi salah satu gerakan utama Samsara untuk mengampanyekan dekriminalisasi aborsi. Penggunaan hashtag ini kerap dilakukan oleh Samsara tidak hanya melalui Instagram, melainkan juga di Twitter maupun Fanspage Samsara Indonesia.

Gerakan "AbortionIsNotaCrime" yang dibawa oleh Samsara melalui gerakan hashtag-nya pada dasarnya merupakan salah satu wujud dari gerakan sosial baru. Gerakan"AbortionIsNotACrime" merupakan gerakan yang berorientasi pada isu aborsi. Isu aborsi hari ini yang berkembang adalah sebuah tindakan pembunuhan janin, sehingga aborsi dianggap sebagai sebuah perilaku kejahatan atau kriminal karena menghilangkan hak hidup. Wacana Inilah yang coba dilawan dan dibangun ulang oleh Samsara dengan gerakan "AbortionIsNotACrime."

Masyarakat luas khususnya dari kalangan pro life atau yang berpihak pada kehidupan 
janin, memahami bahwa aborsi adalah proses pembunuhan. Kalangan pro life ini didominasi oleh kelompok agama maupun masyarakat luas. Alhasil, anggapan aborsi merupakan sebuah bentuk kriminal menjadi konklusi yang terus diproduksi. Bahkan negara pun, sebagai sebuah entitas sosial yang seharusnya memberikan perlindungan terhadap masyarakat khususnya perempuan, mengamini bahwa perilaku aborsi merupakan tindakan yang keliru.

Lawan dari kelompok pro life adalah kelompok pro choice. Kelompok pro choice beranggapan bahwa urusan kehamilan dan kelahiran merupakan otonomi yang seharusnya determinan terhadap perempuan selaku pemilik tubuh. Kelompok pro choice inilah yang terus merawat wacana dekriminalisasi terhadap aborsi dan mendukung terlaksananya aborsi aman. Menata ulang pemahaman masyarakat secara luas mengenai isu aborsi yang selama ini dianggap sebagai sebuah kejahatan atau kriminal memang tidak mudah, sebab wacana aborsi sebagai sebuah 'dosa besar' terlanjur hegemonik.

Gerak sejarah perkembangan masyarakat mengalami proses dialektis. Dialektika mengalami permakanaan sebagai suatu tindakan penguasa atau negara (tidak hanya konteks politik, melainkan eknomi, sosial, dan budaya) akan selalu menimbulkan tanggapan dari masyarakat. Dalam makna bahasa inggris dikatakan sebagao Social Question seperti diungkapkan oleh Francis Wahono, sebagai suatu bentuk kegelisahan masyarakat, aksi perlawanan yang halus ataupun radikal, berbagai bentuk protes (Wahono,

2007).

Gerakan"AbortionIsNotACrime"

sebagaimana tujuan dari gerakan sosial baru adalah untuk menata kembali relasi negara, masyarakat dan ekonomi dan untuk menciptakan ruang publik yang di dalamnya terdapat wacana demokratis otonomi dan kebebasan individual, dalam hal ini terkait dengan aborsi. Artinya, capaian dari gerakan ini diharapkan dapat memberikan layanan aborsi yang aman dan legal dan difasilitasi negara.

\section{Kesimpulan}

Solusi atau langkah yang ditawarkan oleh gerakan "AbortionIsNotACrime" yang dilakukan oleh Samsara beserta jaringannya tentu merupakan upaya yang luar biasa. Persoalan seputar aborsi, seks, seksualitas, dan kesehatan reproduksi selama ini menjadi wacana kamar tidur. Penyebabnya jelas, norma yang berlangsung di masyarakat membuat perempuan ada dalam kondisi yang beresiko tatkala membahas atau bahkan melakukannya. Sejatinya, wacana ini haruslah dibuka secara bebas dan lebih luas sehingga akan menjadi counter wacana yang berguna untuk meluruhkan wacana lama yang lebih merugikan perempuan. Karenanya, gerakan-gerakan yang berbasis pada upaya pencapaian keadilan sosial perlu direproduksi dan didukung secara masif.

Persoalan aborsi haruslah menjadi wacana yang memanusiakan semua pihak yang terlibat. Justifikasi-justifikasi yang berlangsung jelas tak memberi solusi. Alihalih memberikan solusi, yang ada justru menempatkan perempuan semakin rentan dan problematis. Pemerintah Indonesia perlu melihat negara-negara lain yang sudah menerapkan aturan mengenai aborsi yang legal dan aman, serta dilindungi negara. Sudah cukup kredo mengenai aborsi di Indonesia dan bahkan di dunia, membuat perempuan kehilangan otonomi atas tubuhnya. Oleh sebab itu, wacana dekriminalisasi aborsi dan aborsi yang aman harus segera terwujudkan.

\section{Daftar Pustaka}

Basrowi, M. ( 2004). Teori Sosial Dalam Tiga Paradigma. Surabaya: UK Press.

Eriyanto. (2001). Analisis Wacana : Pengantar Analisis Teks Media. LKis: Yogyakarta.

Foucault, Michel. (1995). Dicipline and Punish : The Birth of Prison. New York: Vintage.

Foucault, M. (2009). Pengetahuan dan Metode : Karya-Karya Penting Foucault. Yogyakarta: Jalasutra. 
Foucault, M. (2000). Seks dan Kekuasaan. Jakarta: Gramedia.

Foucault, M. (1976). The Birth of Clinic. London: Tavistock Publication.

Francis, Wahono. (2005). Pangan, Kearifan

Lokal dan Keanekaragaman Hayati.

Yogyakarta: Cindelaras Pustala Rakyat

Cerdas.

Institute, G. (2008). Laporan Aborsi di Indonesia. Guttmacher Institute.

Ipas. (2015). When Abortion IS a Crime: Rwanda From Ipas and The Great Lakes Initiative for Human Rights and Development. United States: Ipas.

Neuman, W. (2003). Social Research Methods : Qualitative and Quantitative Approach. Boston: Allyn and Bacon.

Ritzer, George. (2011). Handbook Teori Sosial. Jakarta: Penerbit Nusa Media.

Walby, S. (2014). Teori Patriarki. Yogyakarta: Jalasutra.

Wijono, D.(2000). Manajemen Mutu

Pelayanan Kesehatan. Surabaya: Airlangga.

\section{Sumber Arsip Internet}

http://health.kompas.com/read/2016/02/ 26/161500423/Begini.Aturan.Aborsi.di.Ind onesia

http://spotlight.ipas.org/movement-forsafe-legal-abortion-goes-global http://www.samsara.or.id/ https://www.instagram.com/samsarayk/ http://www.askinna.com/http://health.ko mpas.com/read/2016/02/26/161500423/ Begini.Aturan.Aborsi.di.Indonesia http://spotlight.ipas.org/movement-forsafe-legal-abortion-goes-global http://www.samsara.or.id/ https://www.instagram.com/samsarayk/ http://www.askinna.com/ 